\title{
Analisis laporan realisasi anggaran pada badan pengelolaan kawasan perbatasan pedalaman dan daerah tertinggal
}

\author{
Gloria Christina $^{1}$, Rusdiah Iskandar ${ }^{2}$, Irwansyah ${ }^{3}$ \\ Fakultas Ekonomi dan Bisnis Universitas Mulawarman, Samarinda. \\ ${ }^{1}$ Email: gloria.christina@mhs.feb.unmul.ac.id \\ ${ }^{2}$ Email: rusdiah.iskandar@feb.unmul.ac.id \\ ${ }^{3}$ Email: irwansyah@feb.unmul.ac.id
}

\begin{abstract}
Abstrak
Dari hasil penelitian analisis varians (selisih) anggaran belanja Badan Pengelolaan Kawasan Perbatasan Pedalaman Dan Daerah Tertinggal Provinsi Kalimantan Timur pada tahun 2011 sebesar 79,19\%, pada tahun 2012 sebesar 80,58\%, padatahun 2013 91,88\%, padatahun 2014 sebesar 91,77\%, dan pada tahun 2015 sebesar 92,50\%. Kinerja anggaran belanja pada Badan Pengelolaan Kawasan Perbatasan Pedalaman Dan Daerah Tertinggal Provinsi Kalimantan Timur dari Tahun Anggaran 2011 sampai dengan Tahun Anggaran 2015 menunjukan kinerja yang baik dikarenakan adanya penghematan penggunaan realisasi Anggaran. Analisis pertumbuhan belanja secara terperinci bahwa belanja tidak angsung dan belanja langsung dari tahun2011-2015 mengalami fluktuasi disetiap tahunnya, hal ini disebabkan jumlah anggaran dan realisasi yang berubah-ubah disetiap tahunnya. Sedangkan rasio efisiensi belanja pada Badan Pengelolaan Kawasan Perbatasan Pedalaman dan Daerah Tertinggal Provinsi Kalimantan Timur selama tahun 2011 - 2015 dikatakan masuk dalam kategori efisiensi karena kurang dari $100 \%$.
\end{abstract}

Kata Kunci: Analisis varians belanja; analisis pertumbuhan belanja

\section{Analyze the budget realization report on the management agency of inland border areas and disadvantaged areas}

\begin{abstract}
From the result of research of analysis of variance (difference) budget of Border Area Management Board of Inland and Disadvantaged Area of East Kalimantan Province in 2011 amounted to 79,19\%, in 2012 equal to 80,58\%, year $201391,88 \%$, year $201491,77 \%$, and by 2015 by $92.50 \%$. Budget performance at Border Area Management Agency of Inland and Disadvantaged Areas of East Kalimantan Province from Fiscal Year 2011 to Budget Year 2015 showed good performance due to savings in the use of budget realization. A detailed growth analysis of expenditures that indirect spending and direct expenditure from 2011-2015 fluctuates every year, due to the varying budget and realization in each year. While the ratio of the efficiency of expenditure on Border Management Board of Inland and Inland Disadvantaged Area of East Kalimantan Province during 2011 - 2015 is said to be included in the category of efficiency because less than 100\%.
\end{abstract}

Keywords: Analysis of variance of expenditure; analysis of spending growth 


\section{PENDAHULUAN}

Di Indonesia, berbagai peraturan dan pedoman telah diterbitkan terkait dengan penerapan penganggaran berbasis kinerja (performance-based budgeting) pada pemerintah daerah. Termasuk yang diatur dalamnya adalah pencantuman indikator kinerja dalam dokumen-dokumen perencanaan dan penganggaran serta penggunaan indikator kinerja tersebut dalam proses penyusunan anggaran pemerintah. Dokumen-dokumen tersebut meliputi Rencana Pembangunan Jangka Menengah Daerah (RPJMD), Rencana Kerja Pemerintah Daerah (RKPD), Kebijakan Umum Anggaran (KUA) serta Prioritas dan Plafon Anggaran Sementara (PPAS) pada tingkat pemerintah daerah (Provinsi/kabupaten/kota). Sedangkan pada tingkat Satuan Kerja Pemerintah Daerah (SKPD) meliputi Rencana Stratejik (Renstra) SKPD, Rencana Kerja (Renja) SKPD dan Rencana Kerja dan Anggaran (RKA) SKPD.

Keselarasan antar dokumen-dokumen perencanaan dapat dilihat dari keselarasan indikator kinerja yang terdapat dalam dokumen- dokumen tersebut. Pada SKPD, indikator kinerja yang dimuat dalam Renja SKPD haruslah mendukung pencapaian indikator kinerja yang termuat dalam Renstra SKPD. Selanjutnya indikator kinerja Renja SKPD harus didukung oleh indikator kinerja yang dimuat dalam RKA SKPD. Adanya keselarasan indikator kinerja ini secara logis akan dapat mengaitkan tujuan-tujuan yang hendak dicapai yang dicantumkan dalam dokumen perencanaan strategis (Renstra SKPD) dengan kegiatan- kegiatan operasional yang dilaksanakan SKPD.

Salah satu prioritas pembangunan pemerintah adalah kawasan-kawasan perbatasan dan tertinggal. Dalam hal ini melalui Peraturan Gubernur Provinsi Kalimantan Timur No. 13 Tahun 2009 dibentuklah Badan Pengelolaan Kawasan Perbatasan, Pedalaman Dan Daerah Tertinggal atau BPKP2DT Provinsi Kalimantan Timur.

Badan Pengelolaan Kawasan Perbatasan Pedalaman dan Daerah Tertinggal Provinsi Kalimantan Timur merupakan salah satu Satuan Perangkat Kerja Pemerintah Daerah di lingkungan Pemerintah Provinsi Kalimantan Timur yang memiliki tugas membuka aksesibilitas dan menghidupkan perekonomian masyarakat di perbatasan, pedalaman dan tertinggal. Berkaitan dengan penggunaan anggaran untuk merealisasikan setiap program kerja Badan Pengelolaan Kawasan Perbatasan Pedalaman dan Daerah Tertinggal Provinsi Kalimantan Timur wajib membuat laporan.

Laporan Realisasi Anggaran (LRA) yang dipublikasikan pemerintah daerah memberikan informasi yang sangat bermanfaat untuk menilai kinerja keuangan daerah. Jika dibandingkan dengan neraca, LRA menduduki prioritas yang lebih penting, dan LRA ini merupakan jenis laporan keuangan daerah yang paling dahulu dihasilkan sebelum membuat lapora neraca, laporan operasional serta laporan arus kas. Anggaran dalam pemerintah merupakan tulang punggung penyelenggaraan pemerintahan dan pembangunan daerah.

Berdasarkan permasalahan tersebut, kinerja aparat pemerintahan khususnya Badan Pengelolaan Kawasan Perbatasan Pedalaman dan Daerah Tertinggal Provinsi Kalimantan Timur sangatlah berperan penting, dalam upaya peningkatan dan pencapaian target-target realisasi anggarannya.

\section{METODE}

Agar dapat memberikan penjelasan mengenai indikator yang digunakan dalam penelitian ini, maka secara operasional dapat dijabarkan sebagai berikut:

1. Badan Pengelolaan Kawasan Perbatasan, Pedalaman dan Daerah Tertinggal Provinsi Kalimantan Timur adalah Satuan Kerja Perangkat Daerah di lingkungan pemerintah Provinsi Kalimantan Timur yang memiliki tugas pokok melaksanakan penyusunan dan melaksanakan kebijakan daerah di rupiah kemudian disusun menurut klasifikasi tertentu secara sistematis untuk suatu periode.

2. Anggaran belanja merupakan rencana

3. keuangan tahunan Badan Pengelolaan Kawasan Perbatasan, Pedalaman dan Daerah Tertinggal Provinsi Kalimantan Timur yang berisi daftar sistematis dan terperinci yang memuat rencana pengeluaran selama satu tahun anggaran.

4. Analisis pertumbuhan belanja adalah analisis yang digunakan Badan Pengelolaan Kawasan Perbatasan Pedalaman dan Daerah Tertinggal Provinsi Kalimantan Timur untuk mengetahui berapa 
besar pertumbuhan belanja yang dapat dipertanggung jawabkan dengan menghitung realisasi belanjanya.

5. Rasio efesiensi belanja adalah peningkatan untuk penghematan Badan Pengelolaan Kawasan Perbatasan Pedalaman dan Daerah Tertinggal Provinsi Kalimantan Timur yang membandingkan realisasi belanja dengan anggaran belanja pada laporan realisasi anggaran.

6. Analisis varians belanja merupakan analisis yang digunakan Badan Pengelolaan Kawasan Perbatasan Pedalaman Dan Daerah Tertinggal Provinsi Kalimantan Timur terhadap selisih antara realisasi belanja dengan anggaran.

7. Belanja langsung adalah belanja yang dianggarkan terkait secara langsung dengan pelaksanaan program dan kegiatan

8. Belanja tidak langsung adalah belanja yang dianggarkan tidak terkait secara langsung dengan pelaksanaan program dan kegiatan.

9. Belanja pegawai adalah kompensasi dalam bentuk uang maupun barang yang diberikan kepada pegawai negeri, pejabat negara dan pensiunan serta pegawai honorer yang akan diangkat sebagai pegawai lingkup Badan Pengelolaan Kawasan Perbatasan Pedalaman Dan Daerah Tertinggal Provinsi Kalimantan Timur sebagai imbalan atas pekerjaan yang telah dilaksanakan dalam rangka mendukung tugas dan fungsi Pemerintah Provinsi Kalimantan Timur.

\section{HASIL DAN PEMBAHASAN}

Pada bagian ini membahas hasil dari analisis varians belanja, analisis pertumbuhan belanja, dan rasio efisiensi belanja pada Badan Pengelolaan Kawasan Perbatasan Pedalaman Dan Daerah Tertinggal Provinsi Kalimantan Timur.

\section{Analisis Varians (Selisih) Anggaran Belanja}

Analisis varians merupakan analisis terhadap perbedaan atau selisih antara realisasi belanja dengan anggaran.Analisis varians cukup sederhana namun dapat memberikan informasi yang sangat berarti. Tahun anggaran 2011 menunjukkan anggaran sebesar Rp11.961.803.460 dan realisasi belanja sebesar Rp9.473.009.120 atau 79,19\% sehingga ini menimbulkan selisih sebesar Rp2.488.794.340 atau 20,81\% yang tidak terealisasi dari total APBD. Jumlah anggaran yang tidak terealisasi dilihat dari presentasenya cukup besar dan nominalnya yang cukup signifikan. Dalam melakukan analisis varians anggaran, hendaknya memperhatikan penghematan yang dilakukan berdasarkan angka presentasi, tetapi juga jumlah nominalnya.Untuk tahun anggaran 2012 selisih anggaran belanja sebesar Rp3.188.090.977 atau 80,58\% dari total APBD. Pada tahun anggaran 2013 selisih anggaran belanja sebesar Rp1.371.491.004 atau 91,88\%. Pada tahun 2014 selisih anggaran belanja sebesar Rp1.509.089.768 atau 91,77\%. Dengan demikian untuk tahun anggaran 2015 anggaran belanja sebesar Rp1.662.782.053,8 atau 92,50\% dari total belanja APBD.

\section{Analisis Pertumbuhan Belanja}

Analisis pertumbuhan belanja daerah bertujuan untuk melihat perkembangan belanja daerah baik belanja tidak langsung maupun belanja langsung dalam perhitungan selama periode yang di analisis.Rasio pertumbuhan ini berguna ntuk mengukur seberapa besar kemampuan pemerintah daerah dalam mempertahankan dan meningkatkan keberhasilan yang telah dicapai pada tahun sebelumnya, baik belanja tidak langsung ataupun belanja langsung.Dari tabel 4.7. dapat dijelaskan secara terperinci bahwa belanja tidak langsung tahun 2011 -2012 mengalami kenaikan sebesar Rp191.689.855 atau 5,10\% yang terdiri dari belanja pegawai. Sedangkan belanja langsung juga mengalami kenaikan sebesar Rp3.565.212.048 atau 62,36\% yang terdiri dari pelayanan administrasi kantor 51,15\% peningkatan sarana dan prasarana aparatur $10,34 \%$ peningkatan disiplin aparatur $22,69 \%$ peningkatan kapasitas sumber daya aparatur 0,3\% Peningkatan Pengembangan Sistem Pelayanan Capaian Kinerja dan Keuangan $38 \%$, pengembangan wilayah perbatasan $89,31 \%$ Peningkatan dan pengembangan pengelolaan keuangan daerah 2,92\% serta Perencanaan pembangunan informasi dan komunikasi 4,34\%. 


\section{Rasio Efisiensi Belanja}

Rasio keserasian menggambarkan bagaimana Badan Pengelolaan Kawasan Perbatasan Pedalaman dan Daerah Tertinggal Provinsi Kalimantan Timur memprioritaskan alokasi dananya pada belanja pembangunan (langsung) danbelanja rutin (tidaklangsung).Jika rasio efisiensinya kurang dari 100\% maka Badan Pengelolaan Kawasan Perbatasan Pedalaman dan Daerah Tertinggal Provinsi Kalimantan Timur dinilai telah melakukan efisiensi anggaran.Sebaliknya jika melebihi $100 \%$ maka mengindikasikan terjadinya pemborosan anggaran. Berdasarkan hasil perhitungan nilai anggaran dan realisasi belanja pada tahun 2011 sebesar 79,19\%, pada tahun 2012 sebesar 80,58\% dan pada tahun 2013 sebesar 85,37\%, pada tahun 2014 sebesar $91,04 \%$ dan pada tahun 2015 sebesar 87,28\%. Pada tabel 4.11. dilihat bahwa dari tahun 2011 -2015 efisiensi anggaran kurang dari 100\% yang berarti bahwa pemerintah daerah telah melakukan efisiensi anggaran.

\section{SIMPULAN}

Berdasarkan analisis data yang telah dilakukan maka dapat disimpulkan bahwa:

1. Dari analisis varians belanja dapat diketahui bahwa kinerjaanggaran belanja Badan Pengelolaa Kawasan Perbatasan Pedalaman dan Daerah TertinggalProvinsi Kalimantan Timurdari Tahun Anggaran 2011sampai dengan Tahun Anggaran 2015 menunjukan kinerja yang baik dikarenakan adanya penghematan penggunaan realisasi anggaran.

2. Analisis pertumbuhan belanja dapat dijelaskan secara terperinci bahwa belanja tidak langsung dan belanja langsung dari tahun 2011-2015 juga mengalami fluktuasi di setiap tahunnya, hal ini di sebabkan jumlah anggaran dan realisasi yg di berubah-ubah di setiap tahunnya.

3. Analisis efisiensi belanja Badan Pengelolaan Kawasan Perbatasan Pedalaman dan Daerah Tertinggal Provinsi Kalimantan Timur efisiensi belanja selama tahun 2011 - 2015 nilai persentasenya hampir rata-rata kuang dari $100 \%$ Jadi efisiensi belanja termasuk dalam katagoripredikat efisiensi karena kurang dari $100 \%$.

\section{DAFTAR PUSTAKA}

Badan Pengawasan Keuangan dan Pembangunan (BPKP). 2005. Pedoman Penyusunan Anggaran Berbasis Kinerja (Revisi). Jakarta

Bahri, Syambudi Prasetia. 2012. Pengaruh Penerapan Anggaran Berbasis Kinerja terhadap Akuntabilitas Kinerja Instansi Pemerintah (Dinas Pendapatan dan Pengelolaan Keuangan Daerah Kota Cirebon). Universitas Pasundan. Bandung.

Bastian, Indra. 2006. Akuntansi Sektor Publik: Suatu Pengantar. Penerbit Erlangga. Jakarta.

Carlin, Tyrone M. 2004. Output Based-Budgeting and the Management of Performance. MGSM Working Papers in Management. Macquarie Graduate School of Management. Sydney Diamond, Jack. 2003. From Program to Performance Budgeting: The Challenge for Emerging Market Economies. IMF Working Paper 03/69. International Monetary Fund. Washington. Diamond, Jack. 2005. Establishing a Performance Management Framework for Government. IMF Working Paper 05/50. International Monetary Fund. Washington.

Halim, Abdul. 2008. Akuntansi Keuangan Daerah. Indeks. Jakarta.

Hou, Yilin. 2010. The Performance of Performance-Based Budgeting in Boom and Bust Years: An Analytical Framework and Survey of States. Prepared for Presentation at the Annual Conference of the American Society for Public Administration (ASPA) San Jose, CA, April 9-13, 2010.

Hughes, Owen E. 1998. Public Management and Administration: An Introduction. Macmillan. Melbourne.

Kementerian Dalam Negeri RI. 2007. Peraturan Menteri Dalam Negeri Nomor 59 Tahun 2007 tentang Revisi atas Peraturan Menteri Dalam Negeri Nomor 13 Tahun 2006 tentang Pedoman Pengelolaan Keuangan Daerah. Jakarta Kementerian Pendayagunaan Aparatur Negara (PAN). 2005. Sistem 
$\overline{\text { Akuntabilitas Kinerja Instansi Pemerintah (SAKIP) dalam Konstelasi Peraturan Perundangan }}$ Manajemen Sektor Publik. Jakarta.

Mahmudi. 2010. Akuntansi Sektor Publik. Ardi Offiset. Yogyakarta.

Mardiasmo. 2005. Akuntansi Sektor Publik. Edisi Kedua. Penerbit Andi. Yoyakarta.

McNab, Robert M. and Francois Melese. 2001. Implementing GPRA: Examining the Prospects for Performance Budgeting in The Federal Goverment.

Peraturan Pemerintah RI Nomor 8 Tahun 2008 tentang Tahapan, Tata Cara Penyusunan, Pengendalian dan Evaluasi Pelaksanaan Rencana Pembangunan Daerah.

Rasul, Sjahruddin. 2003. Pengintegrasian Sistem Akuntabilitas Kinerja dan Anggaran dalam Perspektif UU No. 17/2003 tentang Keuangan Negara. PNRI. Jakarta.

Robinson, Marc and J. Brumby. 2005. Does Performance-Based Budgeting Work?: An Analytical Review of the Empirical Literature.

IMF Working Paper 05/210. International Monetary Fund. Washington.

Rubin, Irene. 2007. Budget Formats: Choices and Implications. Public Sector and Governance and Accountability Series: Local Budgeting. World Bank.

Shah, Anwar and Chunli Shen. 2007. Citizen-Centric Performance Budgeting at the Local Level. Public Sector and Governance and Accountability Series: Local Budgeting. World Bank.

Sarwoko., 2005. Dasar-dasar Ekonometrika. ANDI, Yogyakarta.

Sugiyono., 2007. Statistika untuk Penelitian. Alfabeta, Bandung.

Undang-Undang Nomor 17 Tahun 2003 tentang Keuangan Negara.

Undang-Undang Nomor 23 Tahun 2014 tentang Pemerintahan Daerah.

Undang-Undang Nomor 33 Tahun 2004 tentang Perimbangan Keuangan antara Pemerintah Pusat dan Pemerintah Daerah.

Young, Richard D. 2003. Performance-Based Budget Systems. Public Policy and Practice. Institude for Public Service and Policy Research. University of South Carolina. 